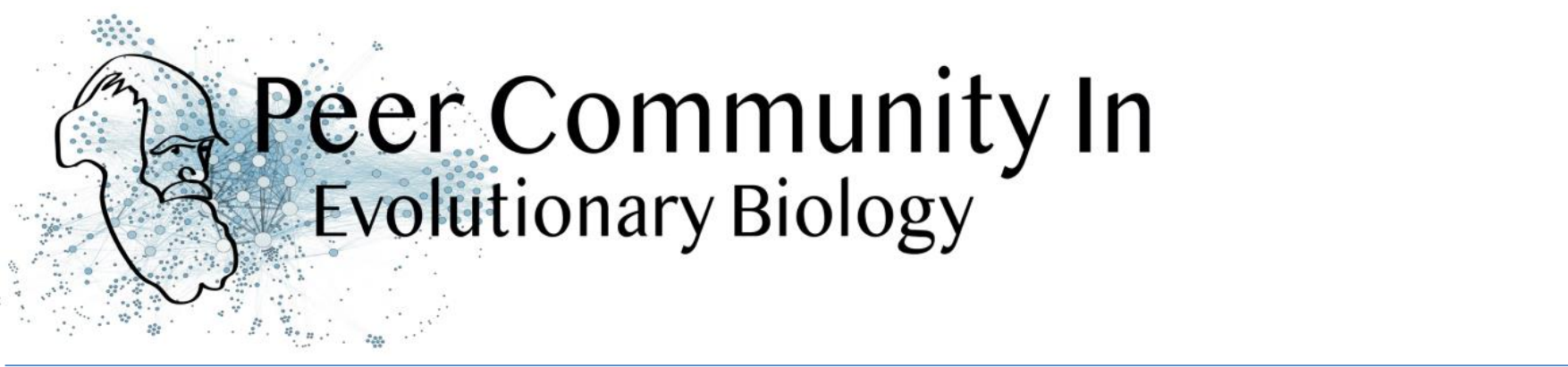

\title{
Durability of plant resistance to diploid pathogen
}

\author{
Hirohisa Kishino based on reviews by Loup Rimbaud and 1 anonymous \\ reviewer
}

\section{A recommendation of:}

\section{Open Access}

Impact of ploidy and pathogen life cycle on resistance durability Méline Saubin, Stephane De Mita, Xujia Zhu, Bruno Sudret, Fabien Halkett(2021), bioRxiv, 2021.05.28.446112, ver. 4 peer-reviewed and recommended by Peer Community in Evolutionary Biologyhttps://doi.org/10.1101/2021.05.28.446112

Published: 26 August 2021

Copyright: This work is licensed under the Creative Commons Attribution-NoDerivatives 4.0 International License. To view a copy of this license, visit http://creativecommons.org/licen ses/by-nd/4.0/

Submitted: 03 June 2021, Recommended: 15 August 2021

\section{Recommendation}

Durability of plant resistance to diploid pathogen Hirohisa Kishino Based on the population genetic and epidemiologic model, Saubin et al. (2021) report that the resistant hosts generated by the breeding based on the gene-forgene interaction is durable much longer against diploid pathogens than haploid pathogens. The avr allele of pathogen that confers the resistance is genetically recessive. The heterozygotes are not recognized by the resistant hosts and only the avr/avr homozygote is adaptive. As a result, the trajectory of avr allele frequency becomes more stochastic due to genetic drift. Although the paper focuses on the evolution of standing polymorphism, it seems obvious that the adaptive mutations in pathogen have much larger probability of being deleted from the population because the individuals own the avr allele mostly in the form of heterozygote at the initial phase after the mutation. Since only few among many models of plant resistance deployment study the case of diploid pathogen and the contribution of the pathogen life cycle, this work will add an important intellect to the literature (Rimbaud et al. 2021).

From the study of host-parasite interaction in flax rust Melampsora lini, Flor $(1942,1955)$ showed that the host resistance is formed by the interaction of a host resistance gene and a corresponding pathogen gene. This gene-for-gene hypothesis has been supported by experimental evidence and has served as a basis of the methods of molecular breeding targeting the dominant $\mathrm{R}$ genes. However, modern agriculture provides the pathogen populations with 


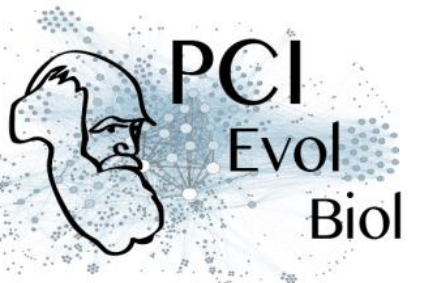

the homogeneous environments and laid strong selection pressure on them. As a result, the newly developed resistant plants face the risk of immediate resistance breakdown (Möller and Stukenbrock 2017).

Currently, quantitative resistance is getting attention as characters as a potential target for long-life (mild) resistant breeds (Lannou, 2012). They are polygenic and controlled partly by the same genes that mediate qualitative resistance but mostly by the genes that encode defenserelated outputs such as strengthening of the cell wall or defense compound biosynthesis (Corwin and Kliebenstein, 2017). Progress of molecular genetics may overcome the technical difficulty (Bakkeren and Szabo, 2020). Saubin et al. (2021) notes that the pattern of genetic inheritance of the pathogen counterparts that respond to the host traits is crucial regarding with the durability of the resistant hosts. The resistance traits for which avr alleles are predicted to be recessive may be the targets of breeding.

\section{References}

Bakkeren, G., and Szabo, L. J. (2020) Progress on molecular genetics and manipulation of rust fungi. Phytopathology, 110, 532-543. https://doi.org/10.1094/PHYTO-07-19-0228-IA

Corwin, J. A., and Kliebenstein, D. J. (2017) Quantitative resistance: more than just perception of a pathogen. The Plant Cell, 29, 655-665. https://doi.org/10.1105/tpc.16.00915

Flor, H. H. (1942) Inheritance of pathogenicity in a cross between physiological races 22 and 24 of Melampsova lini. Phytopathology, 35. Abstract.

Flor, H. H. (1955) Host-parasite interactions in flax rust-its genetics and other implications. Phytopathology, 45, 680-685.

Lannou, C. (2012) Variation and selection of quantitative traits in plant pathogens. Annual review of phytopathology, 50, 319-338. https://doi.org/10.1146/annurev-phyto-081211-173031

Möller, M. and Stukenbrock, E. H. (2017) Evolution and genome architecture in fungal plant pathogens. Nature Reviews Microbiology. 15, 756-771. https://doi.org/10.1038/nrmicro.2017.76

Rimbaud, L., Fabre, F., Papaïx, J., Moury, B., Lannou, C., Barrett, L. G., and Thrall, P. H. (2021) Models of Plant Resistance Deployment. Annual Review of Phytopathology,

59. https://doi.org/10.1146/annurev-phyto-020620-122134

Saubin, M., De Mita, S., Zhu, X., Sudret, B. and Halkett, F. (2021) Impact of ploidy and pathogen life cycle on resistance durability. bioRxiv, 2021.05.28.446112, ver. 4 peer-reviewed and recommended by Peer Community in Evolutionary

Biology. https://doi.org/10.1101/2021.05.28.446112

Cite this recommendation as:

Hirohisa Kishino (2021) Durability of plant resistance to diploid pathogen. Peer Community in Evolutionary Biology, 100131. 10.24072/pci.evolbiol.100131 


\section{Reviews}

\section{Revision round \#1}

\section{Jul 2021}

\section{Author's Reply}

Download author's reply (PDF file)Download tracked changes file

\section{Decision round \#1}

Dear Dr. Méline Saubin,

We received two reviews of your preprint entitled 'Impact of ploidy and pathogen life cycle on resistance durability'. Dr. Loup Rimbaud especially is fully aware of scanty of scientific literature that investigates the effect of the important feature of plant pathogen, ploidy and life cycle, on the resistance durability, appreciates your work. At the same time, both reviewers made useful comments on the validity of the simplified model that the authors adopted. Please revise the manuscript by responding to these comments. This work is focused on the gene for gene interaction, where resistance is usually dominant and infectivity is recessive. Since this model assumption may crucially affect the result of the manuscript, I would ask the authors to include a brief literature review on the biological mechanism behind the model and the evidence sufficient for ruling out the other pattern of genetic inheritance of vir/avir alleles.

Sincerely yours,

Hirohisa Kishino

Preprint DOI: https://doi.org/10.1101/2021.05.28.446112

Reviewed by anonymous reviewer, 29 Jun 2021 19:01

Download the review (PDF file)

Reviewed by Loup Rimbaud, 12 Jul 2021 11:37

Download the review (PDF file) 